\title{
Analysis of Medicago truncatula Nodule Expressed Sequence Tags
}

\author{
János Györgyey, ${ }^{1,2}$ Danièle Vaubert, ${ }^{1}$ José I. Jiménez-Zurdo, ${ }^{1,3}$ Celine Charon, ${ }^{1}$ Liliane Troussard, ${ }^{1}$ \\ Ádám Kondorosi, ${ }^{1}$ and Éva Kondorosi ${ }^{1}$ \\ ${ }^{1}$ Institut des Sciences Végétales, CNRS, 91198 Gif-sur-Yvette, France; ${ }^{2}$ Institute of Plant Biology, Biological \\ Research Center, Hungarian Academy of Sciences, H-6726 Szeged, Hungary; ${ }^{3}$ Departamento \\ de Microbiología del Suelo y Sistemas Simbióticos, Estación Experimental del Zadín, CSIC, 18008 \\ Granada, Spain \\ Accepted 1 October 1999.
}

Systematic sequencing of expressed sequence tags (ESTs) can give a global picture of the assembly of genes involved in the development and function of organs. Indeterminate nodules representing different stages of the developmental program are especially suited to the study of organogenesis. With the vector $\lambda$ HybriZAP, a cDNA library was constructed from emerging nodules of Medicago truncatula induced by Sinorhizobium meliloti. The $5^{\prime}$ ends of 389 cDNA clones were sequenced, then these ESTs were analyzed both by sequence homology search and by studying their expression in roots and nodules. Two hundred fiftysix ESTs exhibited significant similarities to characterized data base entries and 40 of them represented 26 nodulin genes, while 133 had no similarity to sequences with known function. Only 60 out of the 389 cDNA clones corresponded to previously submitted $M$. truncatula EST sequences. For 117 cDNAs, reverse Northern (RNA) hybridization with root and nodule RNA probes revealed enhanced expression in the nodule, 48 clones are likely to code for novel nodulins, 33 cDNAs are clones of already known nodulin genes, and 36 clones exhibit similarity to other characterized genes. Thus, systematic analysis of the EST sequences and their expression patterns is a powerful way to identify nodule-specific and nodulation-related genes.

Interaction between rhizobia and their legume host plants results in the development of nitrogen-fixing root nodules. This specialized plant organ hosts its symbiotic bacterium partners, which convert molecular nitrogen to ammonium accessible for the plant. Nodule organogenesis is controlled by molecular signaling between the plant and the bacterium. In the bacterium, host plant flavonoids induce the synthesis and excretion of the lipochitooligosaccharide Nod signals acting as host-specific morphogens capable of reprogramming differentiated root cortical cells for nodule development.

Corresponding author: Éva Kondorosi

E-mail: Eva.Kondorosi@isv.cnrs-gif.fr

Nucleotide and/or amino acid sequence data can be found at the EMBL data base under accession numbers AJ388667 to AJ389056.
Distinct root cell layers respond differently to Nod factors. In Medicago spp., root hairs and outer cortical cells are involved in the infection process, forming infection threads that transport the bacteria toward the inner cortex. These latter cells are induced for division, leading to the formation of the nodule meristem. Then, cells arrested in division differentiate into various cell types, resulting in the development of the characteristic peripheral and central nodule tissues.

Medicago spp. nodules are of the indeterminate type, having a persistent meristem where, due to the continuous conversion of meristematic cells into distinct nodule cell types, all stages of nodule differentiation are represented. The central region of the indeterminate nodules is built up by three major zones: the apical nodule meristem, where cells proliferate (zone I); the invasion zone, where cells stop to divide and undergo differentiation and became infected with rhizobia (zone II); and the nitrogen fixation zone, where bacteria are converted into nitrogen-fixing bacteroids (zone III) (Schultze and Kondorosi 1998; Long 1996).

Understanding of the molecular basis of nodule development is of importance to highlight the mechanisms of symbiotic nitrogen fixation. Moreover, it may give a better insight into general features of plant organogenesis. Until now, only a few genes, characterized by enhanced expression in nodules, have been identified and their functions in nodule development are still largely unknown. So far, differential and subtractive hybridizations and displays (Gamas et al. 1996; Szczyglowski et al. 1997) as well as "cold plaque screening" (Frugier et al. 1998) have been used to isolate symbiosisrelated genes. The majority of these approaches resulted in the isolation of cDNA clones of highly expressed genes.

Here we present sequence and expression analysis of 389 expressed sequence tags (ESTs) from a nodule cDNA library of $M$. truncatula, which has become a model plant for studying Rhizobium-legume symbiosis (Barker et al. 1990; Blondon et al. 1994; Cook et al. 1997; Hoffmann et al. 1997; Trinh et al. 1998). Systematic sequencing of $M$. truncatula ESTs has been reported so far only for a root hair-enriched cDNA library (Covitz et al. 1998). Our results show that sequencing of ESTs from a nodule cDNA library gives a global view of gene activities in the nodule, and comparison of the expression patterns of cDNAs in the root and nodule provides a powerful way to identify new nodulins or nodule-enhanced genes. 


\section{RESULTS}

\section{Construction of an M. truncatula cDNA library} and sequence analysis of the ESTs.

With polyA $^{+}$mRNA purified from young, white $M$. truncatula nodules induced by the $S$. meliloti strain 41 , a cDNA library was constructed in $\lambda$ HybriZAP. Primary phages $(3.2 \times$ $10^{6}$ ) were obtained with an average insert size of about 1,300 bp and an average insert content of $\geq 95 \%$. Four hundred and eight clones converted into plasmid DNA were sequenced on their $5^{\prime}$ ends. Three hundred eighty-nine out of the 408 clones resulted in readable insert sequences. These sequences have been deposited in the EMBL data base under accession numbers AJ388667 to AJ389056.

Similarities to already characterized data base entries were found for 256 clones, while the rest (133 clones) represented novel genes (Fig. 1A). Ninety-two cDNAs from the latter, unknown category showed no homology to data base entries while 41 did so to ESTs or hypothetical genes without assigned functions from different genome projects. Comparison of the sequences of unknown clones with each other revealed that six genes were represented by two independent cDNA clones and one by a set of three, while the others are probably distinct genes.

The 256 clones with putative functions refer to 221 different genes. These clones were sorted into 12 categories as indi- cated in Figure 1A and listed alphabetically in Table 1. Clones encoding the same function but representing distinct members of a gene family are presented in separate rows. Beside genes involved in primary metabolism (54 clones/51 genes), protein biosynthesis and processing (57 clones/45 genes), nodulins represented the third, most numerous category, with 40 clones of 26 genes.

In the categories of genes with putative functions, 20 genes were represented with more than one cDNA clone as indicated in Table 1. The most abundant ones were the leghemoglobin MtLB1 (Gallusci et al. 1991) and one type of the $40 \mathrm{~S}$ ribosomal protein S8 gene (five clones for each), while $M t L B 2$ was represented by four clones. The overlap of the 389 nodule ESTs with the previously published ESTs of an $M$. truncatula root hair-enriched library (Covitz et al. 1998) was restricted to about $15 \%$ of the clones (60 out of 389). Fifty-six of them possessed significant similarity to genes, particularly in the category of protein synthesis (ribosomal proteins) and primary metabolism (Fig. 1B), while four ESTs with unknown function (MtNo55, 245, 352, 423) were present in both libraries (Covitz at al. 1998). In the category of nodulins, 17 ESTs corresponded to already described nodulins from $M$. truncatula such as MtN1, 4, 5, $16,20,21,22$, and 27 isolated by Gamas et al. (1996) via subtractive hybridization as well as the leghemoglobins MtLB1 and MtLB2 (Gallusci et al. 1991).
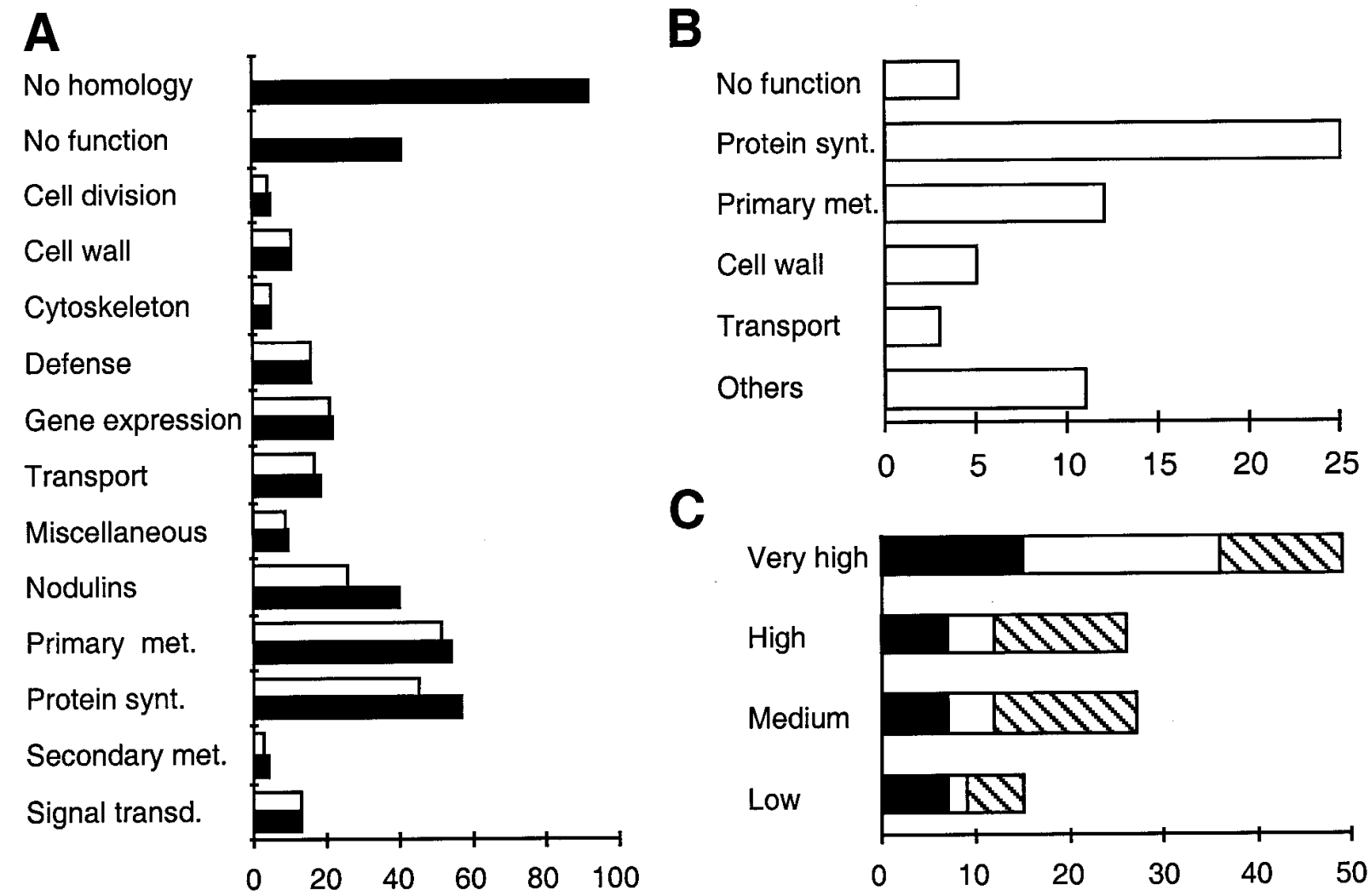

Fig. 1. Distribution of Medicago truncatula EST (expressed sequence tag) clones. A, Functional categories based on data base similarity. Black bar: number of clones in category. White bar: number of genes represented by the clones. B, Overlap of the nodule EST set with the root hair-enriched EST set of $M$. truncatula cv. Jemalong. "Others" represent those functional groups represented only by 1 to 2 clones. C, Distribution of the nodule-enhanced ESTs according to their expression level in the nodule. Black bar: clones with putative function, other than nodulin. White bar: clones similar to known nodulins. Hatched bar: putative new nodulins. 
Table 1. Clones showing similarity to already characterized data base entries

\begin{tabular}{|c|c|c|c|}
\hline Putative gene products by category & Clone no. & Relative transript level $^{a}$ & Relative induction ${ }^{\mathrm{b}}$ \\
\hline \multicolumn{4}{|l|}{ Cell division cycle } \\
\hline Ankyrin-like protein & 174 & Low & 1.1 \\
\hline $\operatorname{cdc} 48$ & 56 & Very high & 22 \\
\hline Hem C / Dim1p homolog & 153 & Low & 0.8 \\
\hline \multicolumn{4}{|l|}{ Cell wall structure or metabolism } \\
\hline Beta-xylosidase & 136 & ND & NA \\
\hline Endo-1,4-beta-glucanase & 117 & ND & NA \\
\hline Expansin & 280 & High & 1.9 \\
\hline Extensin like protein & 425 & Medium & 1.2 \\
\hline Hydroxyproline-rich glycoprotein HRGP1 & 22 & Medium & 1.0 \\
\hline Pectinacetylesterase & 106 & Very high & 110 \\
\hline Pectinacetylesterase (putative) & 252 & Very high & 21 \\
\hline Polygalacturonase precursor (pectinase) & 204 & Low & 1.0 \\
\hline Proline-rich protein PRP4 & 401 & Medium & 0.3 \\
\hline Proline-rich protein (PRP1) & 403 & Very high & 0.7 \\
\hline Proline-rich protein & 96 & Medium & 0.2 \\
\hline \multicolumn{4}{|l|}{ Cytoskeleton } \\
\hline Actin-like protein 2 & 397 & Low & 3.3 \\
\hline Adhesin protein & 77 & Low & 1.2 \\
\hline Annexin & 152 & Low & 1.2 \\
\hline Putative myosin heavy chain & 151 & Low & 1.0 \\
\hline Tubulin beta-1-chain & 367 & Very high & 1.8 \\
\hline \multicolumn{4}{|l|}{ Defense and cell rescue } \\
\hline Acidic chitinase & 103 & Medium & 7.1 \\
\hline Acidic chitinase precursor & 159 & Medium & $>14$ \\
\hline Acidic endochitinase class III & 216 & Low & 1.6 \\
\hline Ascorbate peroxidase & 156 & Very high & 7.1 \\
\hline Cadmium induced protein & 139 & Medium & $>5.6$ \\
\hline Cationic peroxidase 2 & 73 & Medium & 0.6 \\
\hline Cyanase & 71 & Low & 0.8 \\
\hline Ferritin & 358 & Medium & 7.4 \\
\hline Isoflavonoid reductase & 44 & Very high & 2.7 \\
\hline Metallothionein & 295 & High & 1.6 \\
\hline Peroxidase ATP 20a & 246 & Low & 0.8 \\
\hline Phenylalanine ammonia-lyase & 371 & Low & 0.7 \\
\hline RAD6 & 188 & $\mathrm{NM}$ & NA \\
\hline Superoxide dismutase & 213 & Low & $<0.4$ \\
\hline Wound-induced protein & 250 & Low & 1.4 \\
\hline Zeta-crystallin oxidoreductase & 314 & Low & $>1.6$ \\
\hline \multicolumn{4}{|l|}{ Gene expression, chromatin organ isation } \\
\hline ALY transcriptional activator & 141 & Low & $<1.2$ \\
\hline ATP dependent RNA helicase & $281 / 292$ & Medium / Low & $0.7 /<1.2$ \\
\hline bZIP-like protein & 125 & ND & NA \\
\hline DNA topoisomerase III & 181 & Low & $>7.5$ \\
\hline Glycine-rich RNA binding protein & 51 & High & 0.6 \\
\hline Histone H1 & 327 & NM & NA \\
\hline Histone H4 & 391 & Low & 1.2 \\
\hline PcMYB1 protein & 329 & Low & 2.1 \\
\hline PcMYB1 protein & 394 & Medium & 7.0 \\
\hline Poly (A) binding protein & 165 & Low & 1.0 \\
\hline Poly(ADP-ribose) polymerase & 268 & Low & $>1.9$ \\
\hline Polyadenylate binding protein 2 & 186 & Low & 1.6 \\
\hline Putative poly(A)-binding protein & 43 & Very high & 6.8 \\
\hline RING zinc finger protein & 76 & Low & 1.3 \\
\hline RNA polymerase I common subunit & 296 & High & 9.0 \\
\hline RSZp22 / 21 splicing factor & 349 & Medium & 0.8 \\
\hline Scarecrow-like protein & 307 & Low & $>0.9$ \\
\hline SnRNP core protein & 270 & ND & NA \\
\hline SPF1-like DNA-binding protein & 161 & Low & $<1.0$ \\
\hline WRKY3 DNA binding protein & 332 & Very high & 97 \\
\hline Zinc finger protein like & 426 & Low & 2.2 \\
\hline \multicolumn{4}{|l|}{ Membrane transport, intracellular trafficking } \\
\hline ATPase & 283 & Low & 1.4 \\
\hline Chloroplast outer envelope protein & 178 & Very high & 1.1 \\
\hline
\end{tabular}

${ }^{\text {a }}$ Relative transcript levels were classified on the basis of median value of hybridization signals obtained for all clones. NM = not measured due to masking effect of neighboring signals. $\mathrm{ND}=$ not detected.

${ }^{\mathrm{b}}$ Nodules per root. Calculated as the normalized ratio of transcript levels observed in nodule and in root. NA $=$ the ratio cannot be calculated (lack of detection either in the root or both in the root and nodule). 
Table 1. (continued from preceding page)

\begin{tabular}{|c|c|c|c|}
\hline Putative gene products by category & Clone no. & Relative transcript level $^{\mathbf{a}}$ & Relative induction $^{\mathrm{b}}$ \\
\hline Copper transporter protein & 240 & NM & NA \\
\hline Deep orange / PEP3 protein & 63 & ND & NA \\
\hline Kinesin heavy chain isolog & 324 & Very high & 16 \\
\hline Low affinity sulphate transporter & 129 & NM & NA \\
\hline MEM3 / vacuolar transport protein & 66 & Low & $>1.5$ \\
\hline Membrane chanel protein & 143 & Medium & 0.8 \\
\hline MRP-like ABC transporter & 259 & Low & $>2.1$ \\
\hline Putative ammonium transporter & 415 & Low & 0.9 \\
\hline SDF2 secretory protein & 57 & Low & $>2.9$ \\
\hline Sec12p like protein & 128 & Very high & 32 \\
\hline SEC61 transport protein & $111 / 145 / 396$ & Medium & $1.4 / 1.5 / 1.5$ \\
\hline Small GTP-binding protein (RAB1) & 404 & Low & $>2.1$ \\
\hline Small GTP-binding protein SAR1 & 378 & Low & 1.1 \\
\hline Small GTP Binding protein SAR1A & 134 & Low & 1.8 \\
\hline Vacuolar protein sorting homolog, vps 45 & 218 & ND & NA \\
\hline \multicolumn{4}{|l|}{ Nodulins } \\
\hline Early nodulin (N-75) & 229 & High & $>43$ \\
\hline Early nodulin protein ENOD2 & 288 & Very high & $>110$ \\
\hline ENOD40 & 309 & High & 1.9 \\
\hline ENOD93 & 120 & Low & $>1.8$ \\
\hline Leghemoglobin 1 & $113 / 130 / 225 / 232 / 269$ & Very high & $>510 />2100 / 170 / 190 / 260$ \\
\hline Leghemoglobin 2 & $20 / 107 / 140 / 354$ & Very high & $68 />670 />360 / 230$ \\
\hline Leghemoglobin 3 & $215 / 228$ & NM / Very high & NA / 12 \\
\hline Leghemoglobin 4 & $108 / 264 / 298$ & Very high & $>380 />150 />130$ \\
\hline Leghemoglobin 5 & $146 / 168$ & Very high & $>930 />300$ \\
\hline Leghemoglobin 6 & 224 & High & $>27$ \\
\hline Leginsulin, MtN16 & 248 & Medium & 0.7 \\
\hline MtN1 gene & 237 & ND & NA \\
\hline MtN4 gene & 410 & Medium & 3.6 \\
\hline MtN5 gene & 210 & Low & $>1.7$ \\
\hline $\mathrm{MtN} 20$ & 74 & Low & $>9.0$ \\
\hline MtN21 & 62 & ND & NA \\
\hline $\mathrm{MtN} 22$ & 24 & Very high & $>950$ \\
\hline MtN27 & 279 & Medium & $>9.2$ \\
\hline $\mathrm{nms} 22$ & 304 & High & $>350$ \\
\hline nms22 / GRP5 related & $388 / 422$ & High & $69 / 62$ \\
\hline Nodulin 25 like & 94 & Medium & $>12$ \\
\hline Nodulin / GRP5 related & 376 & Medium & 8.8 \\
\hline Nodulin 25 precursor & $154 / 272$ & Very high & $>150 / 110$ \\
\hline Nodulin 26 & 418 & Medium & 12 \\
\hline Nodulin 8 & $81 / 127$ & Very high & $120 />160$ \\
\hline Soybean mRNA for late nodulin & 408 & Low & $>4.8$ \\
\hline \multicolumn{4}{|l|}{ Primary metabolism } \\
\hline 3-Deoxy-D-arabino-heptulosonate-7-phosphate sy nthase & 320 & Low & 1.7 \\
\hline 3-Hydroxy-3-methylglutaril-coenzyme A & 116 & Low & 1.7 \\
\hline Acetoacetyl-CoA-thiolase & 375 & Medium & 1.2 \\
\hline Aconitate hydratase & 88 & ND & NA \\
\hline Acyl carrier protein & 330 & Low & $>1.0$ \\
\hline Adenine nucleotide translocator & 301 & Medium & 0.6 \\
\hline Adenosine kinase & 346 & Low & 0.8 \\
\hline Adenylate kinase & 417 & Medium & 1.8 \\
\hline Alpha amylase precursor & 231 & Low & $<1.0$ \\
\hline Aminolevulinic acid dehydratase & 183 & Low & 1.0 \\
\hline Arabinosidase & 39 & ND & NA \\
\hline Asparagine synthetase & 37 & High & 3.8 \\
\hline ATP synthase beta chain & 299 & Medium & 0.8 \\
\hline ATP synthase delta chain & 389 & Medium & 1.5 \\
\hline Carbonic anhydrase & $131 / 336$ & Very high / Medium & $45 / 6.8$ \\
\hline Chloroplast localized GSII & 29 & Low & 1.6 \\
\hline Choline kinase & 61 & Low & 2.1 \\
\hline Cysteine synthase & $267 / 395$ & Low & $1.3 / 1.5$ \\
\hline Cysteine synthase & 421 & Low & 1.0 \\
\hline CytC reductase hinge prot. Subunit & 35 & Low & 0.9 \\
\hline Cytochrome b5 & 201 & Low & 0.4 \\
\hline Cytosolic fructose-1,6-bis-phosphate ald olase & 65 & Medium & 0.7 \\
\hline Dihydrofolate reductase & 180 & Low & 0.5 \\
\hline Enolase & 60 & Medium & 0.8 \\
\hline Enolase & 414 & ND & NA \\
\hline
\end{tabular}




\section{Leghemoglobins.}

Among nodulins, leghemoglobins were represented by 17 cDNA clones. Multiple alignment of these clones formed six distinct groups, indicating that at least six different leghemoglobin genes (LB1-LB6) were expressed in young nodules of M. truncatula. All leghemoglobin cDNA clones contained a 280-bp-long sequence coding for amino acid residues from positions 47 to139 (LKDSAG . . AYDALA) in the MtLB1 protein. The phylogram of the leghemoglobins shown in Figure 2 was based on this region. Group 1 corresponds to the MtLB1 and group 2 to the MtLB2 (Gallusci et al. 1991), while the other four groups have not been reported yet in M. truncatula. Group 3 was the one most similar to the M. sativa le- ghemoglobin 1 (Barker et al. 1988) and groups 4 and 5 to the M. sativa leghemoglobin 4 (Löbler and Hirsch 1992), while group 6 (MtNo224) showed the highest similarity to the Vicia faba VLB29 at protein level (Frühling et al. 1997).

\section{Expression of ESTs in roots and nodules.}

cDNA inserts of the 389 clones were excised from plasmid DNAs with EcoRI and XhoI digestion and separated by agarose gel electrophoresis. For reverse Northern (RNA) hybridizations two sets of filters were prepared: one was hybridized with nodule-derived and the other with root-derived ${ }^{32} \mathrm{P}$ labeled, first-strand cDNAs synthesized from nodule and root total RNA, respectively. As an example for signals on reverse

Table 1. (continued from preceding page)

\begin{tabular}{|c|c|c|c|}
\hline Putative gene products by category & Clone no. & Relative transcript level $^{\mathrm{a}}$ & Relative induction $^{b}$ \\
\hline Glyoxalase II isozyme & 409 & Low & 2.0 \\
\hline Inorganic pyrophosphatase & 177 & Low & 0.8 \\
\hline Inosine-5'-monophosphate dehydrogenase & 70 & Low & $>4.4$ \\
\hline Kinetoplast methionine synthase & 58 & Medium & 0.4 \\
\hline Lipoxygenase & 115 & Medium & 2.0 \\
\hline Lysophosphatidic acid acyltran sferase & 95 & Very high & 64 \\
\hline Malate dehydrogenase & 97 & Medium & 1.8 \\
\hline Malate dehydrogenase precursor & 72 & Low & 1.0 \\
\hline $\mathrm{N}$-carbamoyl-D-amino acid amidohydrolase & 172 & Low & 0.7 \\
\hline NADH dehydrogenase & 234 & Low & 1.0 \\
\hline NADH-ubiquinone oxidoreductase & 101 & Low & 1.6 \\
\hline Nucleoside diphosphate kinase & 353 & Medium & 1.2 \\
\hline Nucleoside triphosphatase & 313 & Medium & 2.0 \\
\hline Phospholipid glutathione pe roxidase & 289 & Very high & 10 \\
\hline Pyrophospho-fructose-6-phosphate 1-phosphotransferase & 278 & Low & 1.2 \\
\hline Prolyl-4-hydroxylase alpha subunit & 197 & Medium & 1.8 \\
\hline Pyridoxine kinase & 258 & Low & 1.4 \\
\hline S-adenosyl-methionine decarbox ylase & 90 & Low & 1.2 \\
\hline S-adenosyl-methionine sy nthetase & 135 & High & 2.0 \\
\hline S-adenosyl-methionine sy nthetase & 363 & High & 3.0 \\
\hline Sucrose synthase & $257 / 369$ & Medium & $1.3 / 0.8$ \\
\hline Thiazole biosynthetic enzyme & 203 & Low & 1.0 \\
\hline Trehalose-6-phosphate pho sphatase & 79 & Low & $>3.3$ \\
\hline Triosephosphate isomerase & 233 & $\mathrm{NM}$ & NA \\
\hline UDP-glucuronyltransferase & 321 & High & 1.6 \\
\hline Uridylyl transferase & 392 & Low & 2.1 \\
\hline \multicolumn{4}{|l|}{ Protein synthesis and processing } \\
\hline 26S Protease regulatory subunit 4 & 100 & Medium & 1.7 \\
\hline Cysteine proteinase & $99 / 393$ & High & $>130 / 33$ \\
\hline Cysteine proteinase inhib. (cystatin) & 387 & Low & 0.9 \\
\hline Elongation factor 1-alpha & 41,222 & Medium & $1.5 / 0.6$ \\
\hline Initiation factor 2-alpha & 137 & Low & 1.6 \\
\hline Initiation factor $3-\mathrm{p} 40$ & 42 & ND & NA \\
\hline Initiation factor $5 \mathrm{~A}-4$ & 337 & Low & 0.4 \\
\hline Initiation factor $4 \mathrm{~A}-11$ & 331 & Low & 1.0 \\
\hline Serine carboxypeptidase isolog & 207 & Low & $>1.0$ \\
\hline Ubiquitin/CEP52 & 338 & Low & 0.4 \\
\hline Ubiquitin & 416 & Medium & 0.5 \\
\hline Ubiquitin carrier protein E2 & 149 & Low & 1.1 \\
\hline Ubiquitin conjugating enzyme E2 & 413 & Very high & 0.8 \\
\hline $40 S$ ribosomal protein $\mathrm{S} 2$ & 40 & Low & 1.1 \\
\hline $40 \mathrm{~S}$ ribosomal protein $\mathrm{S} 2$, put ative & 377 & High & 3.7 \\
\hline $40 \mathrm{~S}$ ribosomal protein $\mathrm{S} 3 \mathrm{~B}$ & 290 & NM & NA \\
\hline $40 \mathrm{~S}$ ribosomal protein $\mathrm{S} 8$ & $105 / 132 / 293 / 328 / 339$ & Low & $0.8 /<0.8 / \mathrm{NA} />1.9 / 0.5$ \\
\hline 40 S ribosomal protein $S 8$ & 236 & Low & 0.5 \\
\hline $40 \mathrm{~S}$ ribosomal protein $\mathrm{S} 13$ & 98 & Low & 0.9 \\
\hline 40S ribosomal protein S14 & 32 & Medium & 0.6 \\
\hline 40 S ribosomal protein $\mathrm{S} 15$ & 196 & Low & 1.1 \\
\hline 40S ribosomal protein S19 & $23 / 374$ & Medium / Low & $0.8 / 0.7$ \\
\hline $40 \mathrm{~S}$ ribosomal protein $\mathrm{S} 20$ & 274 & Low & $<1.0$ \\
\hline 40S ribosomal protein $\mathrm{S} 26$, putative & $53 / 370$ & Very high & NA / 0.7 \\
\hline
\end{tabular}


Northerns, hybridization of 16 clones (from MtNo295 to MtNo310) with root and nodule cDNA probes is shown in Figure 3. The expression level of the nodulin genes leghemoglobin 4 and $n m s 22$ in the nodules was high as well as that of the MtNo302 and, at a lesser extent, MtNo297, which might be putative new nodulins. The RNA polymerase I common subunit transcript also exhibited a high accumulation level in the nodules. The other clones did not show significant change in their transcript levels; most of them appeared to be constitutive while expression of the AMP-activated protein kinase was at the background level. The vector DNA also gave a nonspecific background signal with the probes that were found even in those samples in which no hybridization was detected with the cDNA insert. This result indicates that separation of the vector and the insert DNA might be essential in the expression stud- ies, since nonspecific signals by the vector DNA may mask the weak specific signals or distort their quantification.

The hybridization signal intensities were quantified by STORM with the ImageQuant software. They were regarded as "detected" if the average value of the hybridization signal of a cDNA fragment was at least $10 \%$ higher than the local background. ESTs were sorted in four categories based on their "relative transcript levels" in the nodule. This was calculated by comparing the expression of each EST with the median value of all detected signals: $50 \%$ of the ESTs possessing weaker signals than the median value were classified in the "low" expression category and the others in the "medium," "high," and "very high" categories when the signal intensities were one to fivefold, five- to 25 -fold, or $>25$-fold higher, respectively, than the median value.

Table 1. (continued from preceding page)

\begin{tabular}{|c|c|c|c|}
\hline Putative gene products by category & Clone no. & Relative transcript level $^{\mathrm{a}}$ & Relative induction $^{\mathrm{b}}$ \\
\hline 40 S ribosomal protein $\mathrm{S} 28$ & 126 & Medium & 1.4 \\
\hline 40S ribosomal protein S29 & 28 & Medium & 1.2 \\
\hline $40 \mathrm{~S}$ ribosomal protein $\mathrm{S} 30$ & 300 & Medium & 1.5 \\
\hline 60 S ribosomal protein L5 & 82 & Low & 0.9 \\
\hline 60S ribosomal protein L6 & $54 / 158 / 261$ & Not det. / NA / Low & NA / NA / 0.9 \\
\hline $60 \mathrm{~S}$ ribosomal protein L6 / L41 & 266 & Medium & 1.0 \\
\hline 60 S ribosomal protein L9 & 310 & Medium & 0.9 \\
\hline 60 S ribosomal protein L14 & 198 & Low & $<0.3$ \\
\hline 60S ribosomal protein L10 & 85 & Medium & 1.6 \\
\hline $60 \mathrm{~S}$ ribosomal protein $\mathrm{L} 10 \mathrm{~A}$ & 241 & Very high & 9.8 \\
\hline 60S ribosomal protein L10A & 382 & Low & 0.9 \\
\hline 60 S ribosomal protein $\mathrm{L} 12$ & 192 & Low & 0.6 \\
\hline $60 \mathrm{~S}$ ribosomal protein $\mathrm{L} 13 \mathrm{a}$ & 38 & Medium & 0.7 \\
\hline $60 \mathrm{~S}$ ribosomal protein L15 & $253 / 306$ & Low / Medium & $0.6 / 0.5$ \\
\hline 60 S ribosomal protein L18 & 308 & Medium & 0.3 \\
\hline $60 \mathrm{~S}$ ribosomal protein $\mathrm{L} 18 \mathrm{~A}$, put ative & 326 & Very high & 24 \\
\hline 60 S ribosomal protein L29 & 348 & Medium & 1.0 \\
\hline $60 \mathrm{~S}$ ribosomal protein L32 & 112 & Medium & 0.8 \\
\hline 60 S ribosomal protein L35 & 114 & Low & 0.8 \\
\hline 60S ribosomal protein L37B & 119 & Low & $<0.4$ \\
\hline Ribosome-associated protein p40 & $138 / 171$ & Low & $>1.0 / 0.8$ \\
\hline \multicolumn{4}{|l|}{ Secondary metabolism } \\
\hline Cytochrome P450 & 184 & Low & 1.3 \\
\hline Cytochrome P450 monoox ygenase & $160 / 194$ & ND / Low & $\mathrm{NA} / 1.0$ \\
\hline Tropinone reductase & 187 & Low & 1.0 \\
\hline \multicolumn{4}{|l|}{ Signal transduction } \\
\hline $14-3-3$ brain protein homolog & $179 / 219$ & Medium & $0.7 / 0.7$ \\
\hline AMP activated protein kinase beta & 303 & ND & NA \\
\hline Calmodulin & 344 & Medium & 8.0 \\
\hline Calmodulin-binding protein & 243 & Very high & 7.8 \\
\hline Calreticulin & 199 & Low & 0.6 \\
\hline GTPase-activiting protein & 176 & ND & NA \\
\hline MAP kinase & 157 & Very high & 26 \\
\hline NPK1-related protein kinase & 316 & Low & $>3.0$ \\
\hline protein kinase homolog & 214 & Low & $>0.9$ \\
\hline Putative receptor protein kinase & 399 & Low & 2.3 \\
\hline Putative serine/ threonine kinase & 400 & Low & $>5.1$ \\
\hline Ras-GTPase-activating protein SH3 & 368 & Low & 1.6 \\
\hline Serine/threonine kinase & 249 & Low & $>1.8$ \\
\hline Small GTP-binding protein & 282 & Low & 1.2 \\
\hline \multicolumn{4}{|l|}{ Miscellaneous } \\
\hline $\mathrm{A} 3$ protein & 277 & Low & 0.9 \\
\hline Axi1 homolog & 155 & ND & NA \\
\hline Cucumber basic protein & 287 & High & 0.5 \\
\hline GA and darkness activated protein & 383 & Low & 1.3 \\
\hline Leginsulin & $142 / 420$ & High & $3.2 / 0.4$ \\
\hline Membrane component B-box protein & 80 & Low & 1.1 \\
\hline Oxysterol-binding protein & 170 & Low & 0.7 \\
\hline Patatin & 317 & Low & 0.8 \\
\hline USF protein homolog & 238 & Low & $<0.5$ \\
\hline
\end{tabular}


For estimation of nodule/root signal ratios hybridization of the cDNA fragments was evaluated by quantification of both the hybridizing bands (object volumes) and the peak values of the signals. The latter was used to avoid errors in the first measurement due to distorted running of DNA fragments. Ratios of both the nodule/root "object volumes" and "object peak" values were calculated and their mean served for the quantification of the relative induction levels. In the case of 53 cDNAs, no hybridization signal was detected with the root-derived probe, indicating that either the corresponding genes were not expressed in roots or their transcript level was below detection. In these cases, the counts detected on the blot at the expected band position were used to calculate the relative enhancement of the transcript level. Differences in the strengths of the probes were filtered out by selecting $37 \mathrm{cDNA}$ clones of constitutively expressed genes including genes of various ribosomal proteins, translation elongation factors, ubiquitins, as well as Msc27 (Crespi et al. 1994) used frequently as constitutive controls for Medicago spp. root and nodule RNA, which served as internal controls for normalizing the signal intensities on filters.

By inspecting the phosphorimager data and the traditional $\mathrm{X}$-ray exposures, we estimated that a two- to 2.5 -fold difference in signal intensity between root and nodule hybridizations revealed significant differences in transcript levels. To be on the safe side and to avoid overestimation of stimulated expression, clones were regarded as "nodule enhanced" only if the ratio of nodule/root signals was $\geq 3$. Based on this criterion, 117 out of the 389 clones showed increased transcript levels in nodules, compared with roots. The relative changes

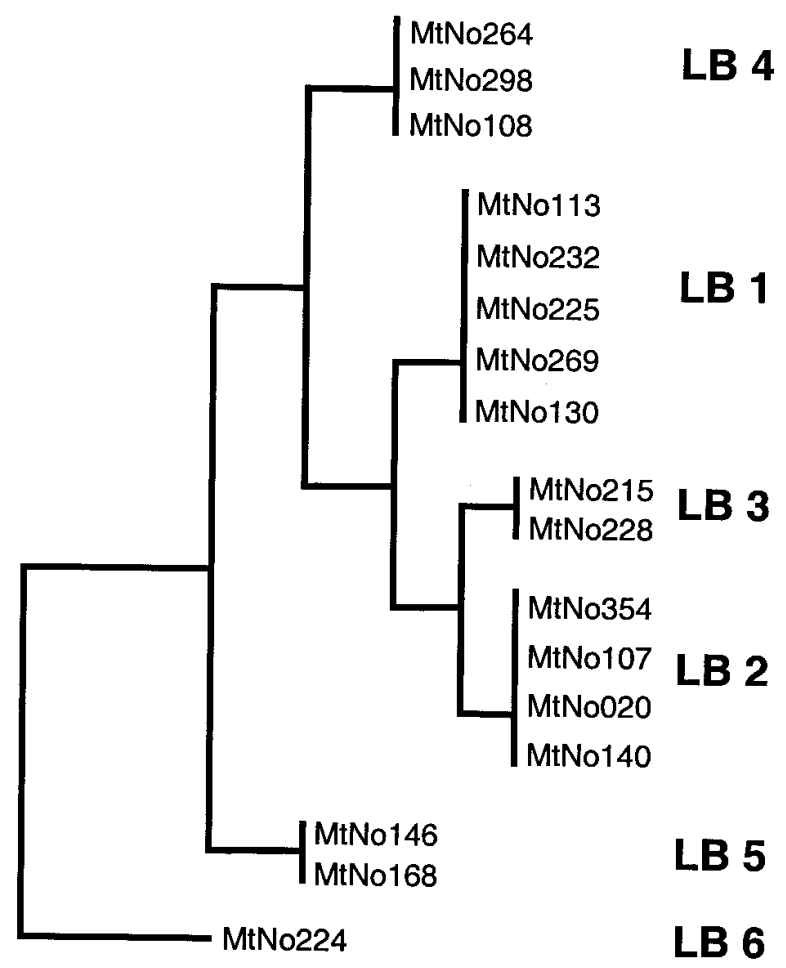

Fig. 2. A phylogram of Medicago truncatula nodule expressed sequence tags (ESTs) coding for leghemoglobin. in transcript levels for all known clones are shown in Table 1, while putative novel nodulins are listed in Table 2. As shown in Figure $1 \mathrm{C}$, in all four transcript level categories noduleenhanced cDNA clones were found.

Thirty-three out of the 40 known nodulin or nodulinhomolog cDNA clones showed the expected, nodule-enhanced expression pattern. However, the MtN1 and MtN21 transcripts (Gamas et al. 1996) were not detectable by reverse Northern and the expression of the MtN16/leginsulin homologue clone even showed a slight decrease. The increases in transcript levels for the enod40 (Crespi et al. 1994), enod93 (Kouchi and Hata 1993), and MtN5 early nodulin genes were below the threefold arbitrary limit. Several-hundred-fold relative increases were observed for transcript levels of most leghemoglobin genes, MtN22 (Gamas et al. 1996), and an nms22-like clone (Ganter et al. 1998).

Thirty-six clones showing similarity to genes encoding known function also showed nodule-enhanced expression. In agreement with a previous report (Coba de la Pena et al. 1997), carbonic anhydrase exhibited strong activation in the nodule. A similar increase in transcript level was observed for pectinacethylesterases, cysteine proteinases, the WRKY3 pathogenesis-induced DNA-binding protein, and the lysophosphatidic acid acyltransferase. Several-fold increase was observed for transcripts of defense-related proteins like chitinases, ascorbate peroxidase, ferritin, and a cadmiuminduced protein. The transcript levels were also elevated for DNA topoisomerase III, a poly-A binding protein and RNA polymerase. Eightfold higher mRNA levels were detected for calmodulin and calmodulin-binding protein genes. Remarkable increases were also observed for certain protein kinases, indicating that signaling pathway components might be transcriptionally activated in the nodule.

In the category of unknown genes, nodule-enhanced expression was observed for 48 clones (Table 2). However, based on their sequence comparisons these clones may represent at most 42 different transcripts since one gene was represented by three clones while four genes were represented by two clones. Three clones exhibited more than hundred-fold in-

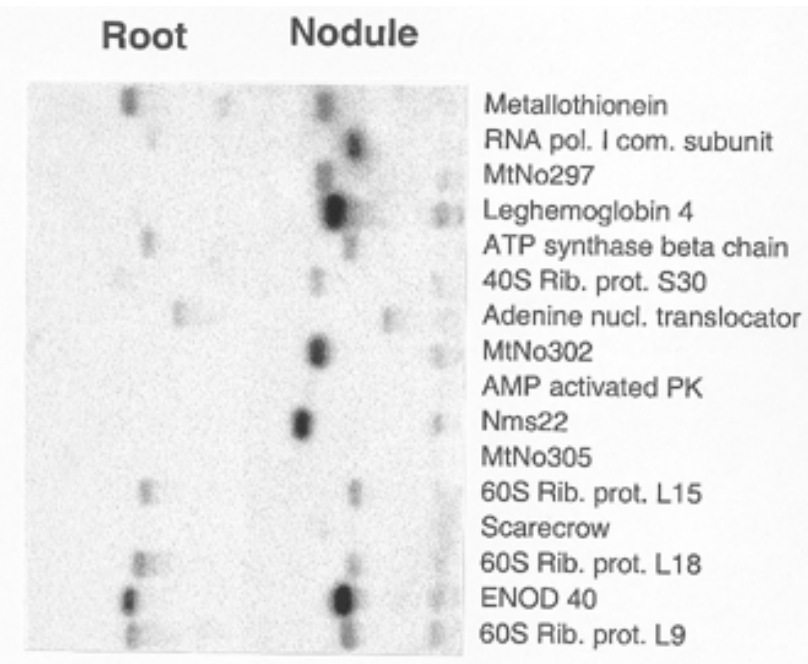

Fig. 3. Comparison of transcript levels of EST (expressed sequence tag) clones MtNo295-MtNo310 in roots and nodules by autography of reverse Northern (RNA) blots. 
creases in the transcript level and another five showed a more than 50-fold increase.

\section{DISCUSSION}

Here we show that systematic sequencing of cDNA clones prepared from young indeterminate nodules, in combination with reverse Northern experiments, is an efficient way to identify new nodulin genes. Compared with previous methods based on various screening approaches, random sequencing of ESTs better reflects the global gene activities involved in nodule development and function. This study demonstrated that $30 \%$ of the ESTs exhibited nodule-enhanced expression, and resulted in the identification of many potential nodulin genes.

The remarkably high ratio of the nodule-enhanced ESTs versus all clones is not surprising in light of the altered cellular structure and physiology of the nodule, compared with root cells (Brewin 1998). For instance, the infection process necessitates the formation of the infection threads, thereby synthesis of new cell wall and matrix components, as well as restruc-

Table 2. List of putative nodulin expressed sequence tag (EST) clones

\begin{tabular}{|c|c|c|c|}
\hline Clone name & Expression & $\begin{array}{c}\text { Relative } \\
\text { induction }\end{array}$ & Insert length $^{a}$ \\
\hline MtNo 68 & Very high & $>242.7$ & 0.63 \\
\hline MtNo 123 & Very high & $>187.0$ & 0.5 \\
\hline MtNo 356 & Very high & 183.7 & 1.77 \\
\hline MtNo 302 / 335 / 263 & High & $>78 / 30 />28$ & $0.48 / 0.49 / 1.22$ \\
\hline MtNo 312 & High & $>71.1$ & 0.64 \\
\hline MtNo 366 & Medium & $>69.7$ & 0.86 \\
\hline MtNo 164 & High & $>61.9$ & 0.56 \\
\hline MtNo 102 / 297 & High, Medium & $>56 />16$ & $0.44 / 0.48$ \\
\hline MtNo 52 & Very high & 34.3 & 0.88 \\
\hline MtNo 166 & Very high & 33.5 & 0.69 \\
\hline MtNo 59 & Medium & $>33.5$ & 0.54 \\
\hline MtNo 21 & Very high & 32.3 & 0.2 \\
\hline MtNo 318 / 133 & High & $>31 />29$ & $0.34 / 045$ \\
\hline MtNo 93 & High & $>26.3$ & 0.44 \\
\hline MtNo 239 & Medium & $>26.3$ & 0.41 \\
\hline MtNo 333 & Very high & 23.4 & 1.0 \\
\hline MtNo 217 & Medium & $>23.2$ & NM \\
\hline MtNo 212 & High & 21.4 & 0.41 \\
\hline MtNo 87 & Very high & 19.9 & 0.4 \\
\hline MtNo 276 & Very high & 19.6 & 0.32 \\
\hline MtNo 92 & High & 16.9 & NM \\
\hline MtNo 262 & Medium & $>16.3$ & 0.7 \\
\hline MtNo 347 & Medium & $>14.3$ & 0.5 \\
\hline MtNo 193 & Medium & $>13.4$ & NM \\
\hline MtNo 286 & Very high & 13.4 & 0.54 \\
\hline MtNo 169 / 372 & Very high & $13 / 3.6$ & $\mathrm{NM} / \mathrm{NM}$ \\
\hline MtNo 230 & Medium & 11.3 & 0.49 \\
\hline MtNo 49 / 208 & Medium & $>8.8 / 5.5$ & $0.75,0.74$ \\
\hline MtNo 390 & Medium & 8.2 & 0.4 \\
\hline MtNo 407 & High & 7.3 & 0.49 \\
\hline MtNo 150 & Medium & 7.0 & 0.56 \\
\hline MtNo 385 & Low & $>6.6$ & 4.31 \\
\hline MtNo 273 & Very high & 6.1 & 0.65 \\
\hline MtNo 91 & High & 5.5 & 0.62 \\
\hline MtNo 89 & Medium & 5.2 & $\mathrm{NM}$ \\
\hline MtNo 360 & Low & 5.1 & 1.05 \\
\hline MtNo 118 & High & 4.7 & 1 \\
\hline MtNo 144 & Low & $>4.7$ & 1.25 \\
\hline MtNo 361 & Low & 4.0 & 1.32 \\
\hline MtNo 294 & Medium & 3.4 & NM \\
\hline MtNo 124 & Low & $>3.3$ & NM \\
\hline MtNo 381 & Low & $>3.0$ & 0.37 \\
\hline
\end{tabular}

${ }^{\mathrm{a}} \mathrm{NM}=$ not measured. turing of the plant cell cytoskeleton. Proline-rich proteins, which are the major components of the infection thread matrix, were also identified as early nodulins (enod12, enod10, enod11). Moreover, nodule cells produce large amounts of membrane materials for the formation of peribacteroid membrane required to envelop the rhizobia when they are released into the cytoplasm of the host cells. The surface of the peribacteroid/symbiosome membrane can exceed that of the plasma membrane by 20 - to 50 -fold and it also determines the type and flux of metabolites exchanged between the nitrogenfixing bacteroids and the plant cell, integrating thereby the bacteroid and plant carbon and nitrogen metabolism. The low oxygen tension is essential for symbiotic nitrogen fixation and the nodule structure provides the microaerobic environment where the oxygen-carrier leghemoglobin represents the most abundant nodulin. Nodule organogenesis also necessitates the activation and differential regulation of the cell cycle at different stages of nodule development.

The cDNA library used in this study was made of young, emerging nodules collected before visible accumulation of leghemoglobin. In the category of known genes, 11 cDNA encoded functions are likely implicated in cell wall or cell wall matrix synthesis, five in cytoskeleton structure, 17 in membrane transport and intracellular trafficking, and 21 in gene expression and chromatin structure. Another 45 cDNAs correspond to genes playing a role in protein synthesis and processing while 51 cDNAs may be involved in primary metabolism and 16 in plant defense and cell rescue. Twenty-six cDNAs showed homology to known nodulin genes, most of them belonging to the group of early nodulins, indicating that in the library the late nodulin genes were not overrepresented. So far only a few cDNAs represent cell cycle genes while a relatively high number of ESTs code for functions that might be implicated in signal transduction pathways. Thus, this relatively small-scale analysis of ESTs appears to be consistent with the expected nodule functions.

The overlap of these nodule ESTs with the ESTs derived from a root hair-enriched cDNA library of $M$. truncatula (Covitz at al. 1998) is restricted to $15 \%$ (60 clones). The majority of these clones code for proteins involved in protein biosynthesis (mainly ribosomal proteins) or in the primary metabolism, which are of universal importance regardless of the cell type. The function of the remaining 4 common clones is unknown. The proportion of the overlapping clones with unknown function (4/133) is about sevenfold lower than that of the overlapping clones with putative functions (56/256). This indicates that sequencing of EST libraries representing distinct organs, tissues, or cell types may reflect drastic and characteristic differences in gene activities.

In reverse Northern hybridizations, the expression profiles of ESTs with the root and nodule probes revealed elevated transcript levels in the nodules for several clones in each category of the known genes, including primary metabolism and protein synthesis. Due to basal levels of expression, the housekeeping genes exhibiting stimulated activity in the nodules could have been lost via subtractive approaches.

The majority of clones classified as nodulins on the basis of sequence similarities showed elevated expression in nodules, indicating that the reverse Northern hybridization is reliable for the identification of new nodulin genes. However, demonstration of the involvement of these putative nodulins in dif- 
ferent phases of nodule development needs more detailed expression studies by focusing on individual genes of interest. Leghemoglobins, identified previously as late nodulins, have been described recently as one of the earliest Nod factorinduced nodulins during nodule organogenesis (Heidstra et al. 1997); therefore, their presence in the young nodule library is not surprising. It was, however, unexpected that they represented six types of leghemoglobin genes and four of them were identified for the first time from $M$. truncatula. The majority of nodulin genes isolated by conventional screening techniques belong to the highly transcribed category. In this study, the putative new nodulin genes were expressed at different levels (from very low to very high), which is another strong argument for the usefulness of the EST transcript profile analysis providing a more comprehensive and reliable way for the isolation of novel nodulins. Our study on the nodule ESTs resulted in the identification of only a fraction of the changes that may occur in gene activities during nodule organogenesis; however, it provided an important glimpse into the likely complexity of gene expression during nodule development.

\section{MATERIALS AND METHODS}

\section{Construction of the cDNA library.}

The cDNA library was constructed in the phage $\lambda$ HybriZAP with the synthesis and cloning kit of Stratagene (La Jolla, CA). Seedlings of M. truncatula line R108 were grown in aeroponic tanks and inoculated with the wild-type $S$. meliloti strain Rm41 as described by Hoffmann et al. (1997). Poly- $\mathrm{A}^{+}$ mRNA was purified from young root nodules 4 to 8 days after Rhizobium infection. The cDNA synthesis of $1.6 \mu \mathrm{g}$ of poly$\mathrm{A}^{+}$mRNA was primed by oligo-(dT)-XhoI adapter primer with MMLV-reverse transcriptase while the second strand was synthesized via polymerase I- ribonuclease $\mathrm{H}$ coincubation. EcoRI adapter was added to the blunted, double-stranded cDNA, followed by XhoI digestion. cDNAs longer than 400 bp were directionally cloned in EcoRI-XhoI digested $\lambda$ HybriZAP phage vector. The library was excised in vivo according to the manufacturer's instructions and pADGal4 phagemid carrying individual bacterial colonies was obtained.

\section{Sequencing and analysis of the EST clones.}

Plasmid DNA minipreps of 408 randomly picked bacterial colonies were made by a modified alkaline lysis method (Feliciello and Chinali 1993). Single run sequencing on the $5^{\prime}$ ends of each cDNA clone was performed on an Applied Biosystems 373A sequencer (Applied Biosystems, Foster City, CA) with the BigDyeTerminator kit and AcGal3SE primer $\left(5^{\prime}\right.$ ATT CGA TGA TGA AGA TAC CCC 3') located in the Gal4 activator domain sequence of the phagemid upstream of the EcoRI cloning site. Fifty-five clones were also sequenced on the $3^{\prime}$ ends with standard T7 primer (5' GTA ATA CGA CTC ACT ATA GGG C 3').

Classification of the clones was based on their similarity to data base entries. In general, 450 to 500 nucleotides following the EcoRI adapter sequence were taken for data base comparisons with the BlastN program for nucleic acids and the BlastX program for proteins at the NCBI web server (Altschul et al. 1997). Default parameters of the programs were used in both cases. Usually, similarities having random probabilities higher than $10^{-7}$ were considered to be significant. Comparisons and alignments of the EST sequences were performed with the GCG program package (Genetics Computer Group, Madison, WI).

\section{Reverse Northern hybridization.}

Plasmid DNA ( 0.5 to $1 \mu \mathrm{g}$ ) of each clone was digested with EcoRI and XhoI restriction enzymes. For preparation of two sets of filters, equal volumes from each digestion were subjected to electrophoresis on two identical 1\% TBE (Trisborate-EDTA) agarose gels. Gels were transferred via alkaline downward blotting to BioTrans (ICN, Costa Mesa, CA) nylon membranes (Chomczynski 1992) and immobilized via UV crosslinking according to the manufacturer's instructions.

Radiolabeled cDNA probes were synthesized by reverse transcription of $15 \mu \mathrm{g}$ of total RNA for $1 \mathrm{~h}$ in the presence of $50 \mu \mathrm{Ci} \alpha\left[{ }^{32} \mathrm{P}\right]$-dCTP with the Superscript reverse transcriptase kit (Gibco-BRL/Life Technologies, Gaithersburg, MD) as described by Charon et al. (1997). The total RNA samples from roots and nodules were isolated 21 days after the inoculation of the plants with the $\mathrm{Nod}^{-}$mutant $S$. meliloti strain ZB138 (Kondorosi et al. 1984) and the wild-type strain Rm41, respectively. To complete cDNA synthesis, reactions were prolonged for $45 \mathrm{~min}$ with $1 \mathrm{mM}$ cold dCTP. Unincorporated dNTPs were removed by purification with a Sephadex G-50 column and labeling efficiency was measured by scintillation counting. The filters were hybridized, one set with each probe, in $0.5 \mathrm{M}$ Na-phosphate $\mathrm{pH} 7.2,7 \%$ SDS (sodium dodecyl sulfate) buffer (Church and Gilbert 1984) for $36 \mathrm{~h}$ at $65^{\circ} \mathrm{C}$, then washed for $30 \mathrm{~min}$ each with $2 \times \mathrm{SSC}(1 \times \mathrm{SSC}$ : $0.15 \mathrm{M} \mathrm{NaCl}$, $0.015 \mathrm{M}$ sodium citrate) / $0.1 \%$ SDS and $1 \times \mathrm{SSC} / 0.1 \%$ SDS. Hybridization signals were observed first on Kodak X-ray films and then quantified on a STORM phosphorimager (Molecular Dynamics, Sunnyvale, CA) after 2 to $20 \mathrm{~h}$ of exposure.

\section{ACKNOWLEDGMENTS}

We are grateful to Martin Crespi and Michael Schultze for their help in the construction of the cDNA library. This work is part of the Genome Programs of CNRS and INRA on Medicago truncatula. J. G. was supported by an EMBO Long Term Fellowship ALTF 811-1996 and by the "Jumelage" program between the CNRS and the Hungarian Academy of Sciences, while J. I. J.-Z. was supported by the EC Marie Curie Fellowship Program (EC BIO4CT975006).

\section{LITERATURE CITED}

Altschul, S. F., Madden, T. L., Schaffer, A. A., Zhang, J., Zhang, Z., Miller, W., and Lipman, D. J. 1997. Gapped BLAST and PSI-BLAST: A new generation of protein database search programs. Nucleic Acids Res. 25:3389-3402.

Barker, D. G., Gallusci, P., Lullien, V., Khan, H., Gherardi, M., and Huguet, T. 1988. Identification of two groups of leghemoglobin genes in alfalfa (Medicago sativa) and a study of their expression during root nodule development. Plant Mol. Biol. 11:761-772.

Barker, D. G., Bianchi, S., Blondon, F., Dattée, Y., Duc, G., Essad, S., Flament, P., Gallusci, P., Génier, G., Guy, P., Muel, X., Tourneur, J., Dénarié, J., and Huguet, T. 1990. Medicago truncatula, a model plant for studying the molecular genetics of the Rhizobium-legume symbiosis. Plant Mol. Biol. Rep. 8:40-49.

Brewin, N. J. 1998 Tissue and cell invasion by Rhizobium: The structure and development of infection threads and symbiosomes. Pages 417 429 in: The Rhizobiaceae. H. P. Spaink, A. Kondorosi, and P. J. J. Hooykaas, eds. Kluwer Academic, Dordrecht, The Netherlands. 
Blondon, F., Marie, D., Brown, S., and Kondorosi, A. 1994. Genomic size and base composition in Medicago sativa and Medicago truncatula species. Genome 37:264-270.

Charon, C., Johansson, C., Kondorosi, E., Kondorosi, A., and Crespi, M. D. 1997. Enod40 induces dedifferentiation and division of root cortical cells in legumes. Proc. Natl. Acad. Sci. USA 94:8901-8906.

Chomczynski, P. 1992. One-hour downward alkaline capillary transfer for blotting of DNA and RNA. Anal. Biochem. 201:134-139.

Church, G. M., and Gilbert, W. 1984. Genomic sequencing. Proc. Natl. Acad. Sci. USA 81:1991-1995.

Coba de la Pena, T., Frugier, F., McKhann, H. I., Bauer, P., Brown, S. Kondorosi, A., and Crespi, M. 1997. A carbonic anhydrase gene is induced in the nodule primordium and its cell-specific expression is controlled by the presence of Rhizobium during development. Plant J. 11:407-420.

Cook, D. R., Vandenbosch, K., de Bruijn F. J., and Huguet, T. 1997. Model legumes get the nod. Plant Cell 9:275-281.

Covitz, P. A., Smith, L. S., and Long, S. R. 1998. Expressed sequence tags from a root hair-enriched Medicago truncatula cDNA library. Plant Physiol. 117:1325-1332.

Crespi, M. D., Jurkevitch, E., Poiret, M., d'Aubenton-Carafa, Y., Petrovics, G., Kondorosi, E., and Kondorosi, A. 1994. enod40, a gene expressed during nodule organogenesis, codes for a non-translatable RNA involved in plant growth. EMBO J. 13:5099-5112.

Feliciello, I., and Chinali, G. 1993. A modified alkaline lysis method for the preparation of highly purified plasmid DNA from Escherichia coli. Anal. Biochem. 212:394-401.

Frugier, F., Kondorosi, A., and Crespi, M. 1998. Identification of novel putative regulatory genes induced during alfalfa nodule development with a cold-plaque screening procedure. Mol. Plant-Microbe Interact. 11:358-366.

Frühling, M., Roussel, H., Gianinazzi-Pearson, V., Pühler, A., and Perlick, A. M. 1997. The Vicia faba leghemoglobin gene VfLb29 is induced in root nodules and in roots colonized by the arbuscular mycorrhizal fungus Glomus fasciculatum. Mol. Plant-Microbe Interact. 10:124-131.

Gallusci, P., Dedieu, A., Journet, E. P., Huguet, T., and Barker, D. G. 1991. Synchronous expression of leghaemoglobin genes in Medicago truncatula during nitrogen-fixing root nodule development and re- sponse to exogenously supplied nitrate. Plant Mol. Biol. 17:335-349.

Gamas, P., de Carvalho Niebel, F., Lescure, N., and Cullimore, J. V. 1996. Use of a subtractive hybridization approach to identify new Medicago truncatula genes induced during root nodule development. Mol. Plant-Microbe Interact. 9:233-242.

Ganter, G., Raja, S., and Dunn, K. 1998. The cDNA sequence of nms 22 (accession no. AF030252), a gene whose message is specific to the infected cells of alfalfa (Medicago sativa) root nodules (PGR98-009). Plant Physiol. 116:446.

Heidstra, R., Nilsen, G., Martinez-Abarca, F., van Kammen, A., and Bisseling, T. 1997. Nod factor-induced expression of leghemoglobin to study the mechanism of $\mathrm{NH}_{4} \mathrm{NO}_{3}$ inhibition on root hair deformation. Mol. Plant-Microbe Interact. 10:215-220.

Hoffmann, B., Trinh, T. H., Leung, J., Kondorosi, A., and Kondorosi, E. 1997. A new Medicago truncatula line with superior in vitro regeneration, transformation, and symbiotic properties isolated through cell culture selection. Mol. Plant-Microbe Interact. 10: 307-315.

Kondorosi, E., Bánfalvi, Z., and Kondorosi, A. 1984. Physical and genetic analysis of a symbiotic region of Rhizobium meliloti: Identification of nodulation genes. Mol. Gen. Genet. 193:445-452.

Kouchi, H., and Hata, S. 1993. Isolation and characterization of novel nodulin cDNAs representing genes expressed at early stages of soybean nodule development. Mol. Gen. Genet. 238:106-19.

Löbler, M., and Hirsch, A. M. 1992. An alfalfa (Medicago sativa L.) cDNA encoding an acidic leghemoglobin (MsLb3). Plant Mol. Biol. 20:733-736.

Long, S. R. 1996. Rhizobium symbiosis: Nod factors in perspective. Plant Cell 8:1885-98.

Schultze, M. and Kondorosi, A. 1998. Regulation of symbiotic root nodule development. Annu. Rev. Genet. 32:33-57.

Szczyglowski, K., Hamburger, D., Kapranov, P., and de Bruijn, F. J. 1997. Construction of a Lotus japonicus late nodulin expressed sequence tag library and identification of novel nodule-specific genes. Plant Physiol. 114:1335-46.

Trinh, T. H., Ratet, P., Kondorosi, E., Durand, P., Kamate, P., Bauer, P., and Kondorosi, A. 1998. Rapid and efficient transformation of diploid Medicago truncatula and Medicago sativa ssp. falcata lines improved in somatic embryogenesis. Plant Cell Rep. 17:345-355. 